Article

\title{
Dynamic Change Characteristics of Groundwater Affected by Super-Long Tunnel Construction in the Western Mountainous Area of China
}

\author{
Zhiqiang Zhang ${ }^{1,2}$, Peng $\mathrm{Xu}^{1,2}$, Heng Zhang ${ }^{1,2, *}$ and Kangjian Zhang ${ }^{1}$ \\ 1 School of Civil Engineering, Southwest Jiaotong University, Chengdu 610031, China; \\ clark@swjtu.edu.cn (Z.Z.); xpjuju1213@outlook.com (P.X.); zkj130281@outlook.com (K.Z.) \\ 2 Key Laboratory of Transportation Tunnel Engineering, Ministry of Education, Southwest Jiaotong University, \\ Chengdu 610031, China \\ * Correspondence: tunnelzh@home.swjtu.edu.cn; Tel.: +86-028-8763-4386
}

Received: 13 March 2019; Accepted: 12 April 2019; Published: 18 April 2019

check for updates

\begin{abstract}
The problem of groundwater is very prominent in super-long tunnel construction, which brings serious potential safety hazards and economic losses to the project. The knowledge of dynamic change characteristics of groundwater and prediction of water inflow is the key to ensure rational design and safe construction in super-long tunnel. In this paper, numerical simulation and in situ observation are conducted to investigate dynamic change characteristics of groundwater and the prediction of water inflow based on the Daxiangling tunnel in Sichuan Province of China. The results show that the numerical model established with detailed geological data and validated with field monitoring data can effectively analyze dynamic change characteristics of groundwater, as well as predict water inflow. The initial state of groundwater is steady when the tunnel is unexcavated. Tunnel excavation has a significant influence on the distribution of groundwater. The flow direction of groundwater will change, and the contour lines of groundwater will be intensive at the tunnel face. These changes will be more obvious and dramatic when the tunnel is excavated into the fault zone, which is a signal that the water inrush is more likely to occur in the fault zone because of a lot of joints and fractures. A connected linear cavity is formed with tunnel holing-through and groundwater begins to flow vertically downwards to the tunnel. As far as the prediction of water inflow is concerned, the numerical method can more precisely calculate the value of water inflow with less than 15 percent relative error compared with the groundwater dynamics method.
\end{abstract}

Keywords: super-long tunnel; dynamic change characteristics; prediction of water inflow; in-situ observation; numerical simulation

\section{Introduction}

The past decades have witnessed an unprecedented period of growth in tunnel construction in China. By the end of 2017, the number of highway tunnels in China was 16,229 and the total length was $15,285 \mathrm{~km}[1,2]$. In the same year, the number and the total length of railway tunnels in China were 14,547 and 15,326 km [3-5]. The total length statistics of highway tunnels in China from 2005 to 2017 are shown in Figure 1a, and the total length statistics of railway tunnels are shown in Figure $1 \mathrm{~b}$. At present, China has developed into one of the countries with the largest tunnel scale, the largest number of tunnels, the most complex tunnel structure. and the most complicated tunnel construction technology in the world [6-12]. 


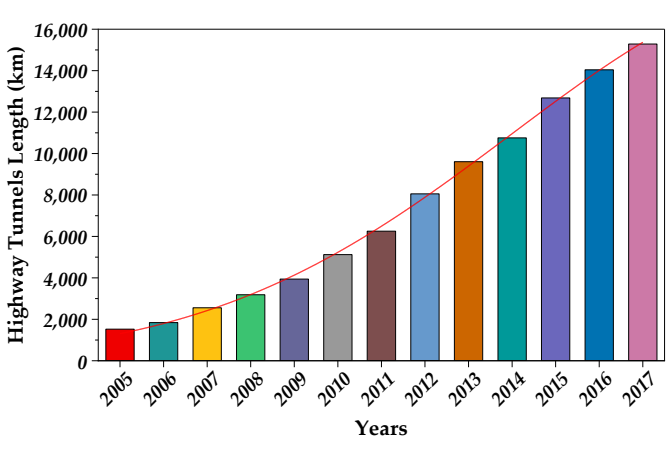

(a)

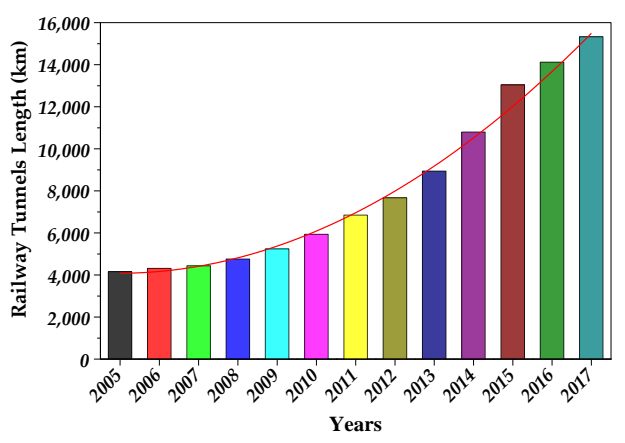

(b)

Figure 1. The total length of tunnels in China from 2005 to 2017. (a) Highway tunnels; (b) railway tunnels.

In recent years, the focus of tunnel construction has shifted to the western mountainous areas with the advancement of the western development strategy. Western mountainous areas are mainly located in the first and second levels of the terrain ladder in China, with complex engineering geological conditions, frequent crustal movement, widely distributed fault zones, multiple geological hazards, abundant water resources, and fragile ecological environment. During the construction for super-long tunnels in western mountainous areas, it is inevitable to encounter various problems caused by groundwater [13-17]. On the one hand, the excavation of the tunnel will break the initial equilibrium of groundwater, destroy the initial circulating recharge system, and change the initial flow state of groundwater [18-21]. The seepage state of groundwater in rock and soil is bound to change [22-24]. On the other hand, groundwater, in turn, will reduce the strength of surrounding rock through segmentation, softening, and dissolution. At the same time, groundwater will damage tunnel structure, weaken its bearing capacity, and affect its service life. In the absence of timely support, the destruction of the initial soil and water balance system will lead to water inrush during tunnel construction. Once the disaster occurs, the tunnel will be blocked, and construction facilities will be washed away, leading to construction stoppage. More seriously, water inrush will not only cause great loss of life and property, but also bring about a series of negative environmental effects, such as surface subsidence, water depletion, groundwater pollution, and ecological environment deterioration [25]. Due to the sudden occurrence of water inrush and the uncertainty of its location, it has become one of the most common and harmful geological hazards in tunnel construction. Examples of water inrush accidents in tunnel construction at home and abroad are shown in Table 1 [26-30]. Therefore, it is of great engineering significance to investigate dynamic change characteristics of groundwater and the prediction of water inflow affected by super-long tunnel construction in the western mountainous area of China.

Table 1. Examples of tunnel water inrush accidents at home and abroad.

\begin{tabular}{cccl}
\hline Country & Tunnel & $\begin{array}{c}\text { Length } \\
(\mathbf{k m})\end{array}$ & \multicolumn{1}{c}{ Accident Survey } \\
\hline $\begin{array}{c}\text { Between } \\
\begin{array}{c}\text { Switzerland } \\
\text { and Italy }\end{array}\end{array}$ & $\begin{array}{c}\text { Simpland } \\
\text { Tunnel }\end{array}$ & 19.8 & $\begin{array}{l}\text { Several extraordinarily serious water inrush accidents happened. The } \\
\text { water inflow of the largest one was } 11.16 \times 10^{6} \mathrm{~m}^{3} / \mathrm{d} \text {, resulting in a } \\
\text { budget overrun of } 500 \% \text { and a delay of } 18 \text { months. }\end{array}$ \\
\hline Japan & $\begin{array}{c}\text { Tanna } \\
\text { Tunnel }\end{array}$ & 7.8 & $\begin{array}{l}\text { There were } 6 \text { serious water inrush accidents in construction. The } \\
\text { maximum water inflow through fault fracture zone is } 19.35 \times 10^{4} \mathrm{~m}^{3} / \mathrm{d} \\
\text { and the amount of projecting mud soil is more than } 7000 \times 10^{4} \mathrm{~m}^{3} / \mathrm{d} . \\
\text { Construction time is up to } 16 \text { years. }\end{array}$ \\
\hline $\begin{array}{c}\text { The Soviet } \\
\text { Union }\end{array}$ & $\begin{array}{c}\text { Beimu } \\
\text { Tunnel }\end{array}$ & 15.3 & $\begin{array}{l}\text { A serious water inrush occurs during passing through the erosion area. } \\
\text { The maximum water inflow is } 60 \times 10^{4} \mathrm{~m}^{3} / \mathrm{d} \text {. The project was delayed by } \\
\text { two years. }\end{array}$ \\
\hline
\end{tabular}


Table 1. Cont.

\begin{tabular}{|c|c|c|c|}
\hline Japan & $\begin{array}{l}\text { Seikan } \\
\text { Tunnel }\end{array}$ & 53.5 & $\begin{array}{l}\text { During the construction of the tunnel, there have been many times of } \\
\text { water inrush with the water inflow of } 11.52 \times 10^{4} \mathrm{~m}^{3} / \mathrm{d} \text {, resulting in } 34 \\
\text { deaths and a total delay of } 10 \text { years. }\end{array}$ \\
\hline China & $\begin{array}{c}\text { Samurada } \\
\text { Tunnel }\end{array}$ & 6.38 & $\begin{array}{l}\text { The maximum inflow of water reached } 5.2 \times 10^{4} \mathrm{~m}^{3} / \mathrm{d} \text {, resulting in a } \\
\text { stoppage of work for } 32 \text { days. After operation, the tunnel was seriously } \\
\text { leaking, costing nearly } 10 \text { million yuan to renovate. }\end{array}$ \\
\hline China & $\begin{array}{l}\text { Nanling } \\
\text { Tunnel }\end{array}$ & 6.7 & $\begin{array}{l}\text { The inflow of water was as high as } 2.2 \times 10^{4} \mathrm{~m}^{3} / \mathrm{d} \text {, causing the } \\
\text { Beijing-Guangzhou railway to sink, and the renovation period lasted for } \\
\text { three years. }\end{array}$ \\
\hline China & $\begin{array}{c}\text { Yuanliang } \\
\text { Mountain } \\
\text { Tunnel }\end{array}$ & 11.18 & $\begin{array}{l}\text { During the tunnel construction, the massive water inrush occurred many } \\
\text { times. The maximum water inflow reached } 6.9 \times 10^{4} \mathrm{~m}^{3} / \mathrm{d} \text {, which caused } \\
\text { the surface collapse and delayed the construction period. }\end{array}$ \\
\hline China & $\begin{array}{l}\text { Huaying } \\
\text { Mountain } \\
\text { Tunnel }\end{array}$ & 9.4 & $\begin{array}{l}\text { There have been several serious water inrush accidents, the most serious } \\
\text { of which was a water inflow of } 69 \times 10^{4} \mathrm{~m}^{3} / \mathrm{d} \text {. The construction } \\
\text { equipment was damaged and the tunnel was blocked. The project was } \\
\text { forced to stop working for nearly } 3 \text { months. }\end{array}$ \\
\hline
\end{tabular}

The law and characteristics of groundwater movement are intricate because of the complex engineering geological conditions of tunnels in western mountainous areas [31,32]. The traditional problem of groundwater movement is mainly analyzed by analytical methods. A large amount of simplification and assumptions are usually made to solve the problem through mathematical analysis. With the deepening of the study on the law and characteristics of groundwater movement, the development of analytical methods under ideal conditions has encountered great resistance. Since the 1970s, the numerical method has gradually become the mainstream method to solve groundwater motion. At present, scholars at home and abroad have carried out extensive research on groundwater the seepage field, which is one aspect of groundwater movement. The distribution law of water seepage field and the coefficient of water pressure in the surrounding rock of mountain tunnels under high water pressure and permeability conditions were analyzed by Gao et al. [33] through indoor model test. Based on the steady-state seepage control equation and the conformal transformation method, Zhu et al. [34] deduced the analytical solution of the seepage field in underwater tunnels. Zhu et al. [35] rigorously derived the semi-analytical solutions of the seepage field of twin tunnels considering the effect of lining by using the technique of conformal mapping based on the governing equation of steady-state seepage. Li et al. [36] deduced the hydraulic pressure formula of the seepage field considering the surrounding rock, grouting ring, and lining as a complete system combined with the actual hydrological environment on the basis of the classical solution of Harr. Zhang et al. [37] proposed a numerical method based on the nonlinear finite element method to simulate the influence of non-Darcy seepage on the tunnel.

The most intuitive and harmful result of groundwater movement to tunnel is water inrush. The research on the prediction of water inflow has been ongoing for half a century. A reasonable prediction of tunnel water inflow is very important for tunnel waterproofing and drainage design, and related to the safety of the surrounding ecological environment [38]. At present, lots of prediction methods for water inflow have been developed, which are mainly divided into deterministic prediction models and non-deterministic prediction models. Deterministic prediction models include the water equalization method, groundwater dynamics method, numerical simulation method, and physical simulation method. Non-deterministic prediction models include the hydrogeological analogy method, scoring method, isotopic atmosphere method, time series analysis, fuzzy mathematical model, $\mathrm{BP}$ artificial neural network, and so on. With the development of computer technology and a large number of groundwater simulation software, the numerical simulation method has been adopted by more researchers by virtue of its advantages in describing complex structures and boundary conditions accurately [39]. In the study of tunnel water inflow prediction, Lin et al. [40] analyzed the advantages, the disadvantages, and applicable conditions of various prediction methods for tunnel water inflow in 
karst areas, divided the karst areas with different water-bearing geological structures, and proposed a corresponding reasonable prediction method for tunnel water inflow. Under different grouting ring and initial lining permeability coefficients, $\mathrm{Li}$ et al. [41] studied the prediction of tunnel water inflow without considering the influence of tunnel excavation disturbance by using the tunnel seepage model test system. Hwang et al. [42] proposed a semi-analytical approach for analyzing the problems of the tunnel water inflow and used this method to simulate the influent conditions of two tunnels. Li et al. [43] used the numerical simulation method to analyze the distribution law of pore water pressure and water inflow in the surrounding rock of a double-arched tunnel and continuous tubular tunnel, and predicted the location of leakage of two types of tunnels. Cheng et al. [44] introduced an empirical correlation about the permeability coefficient changing with depth in order to assess the water inflow, which is more suitable to the actual conditions of the tunnel. Li et al. [45] presented a new water inflow prediction technique by using the nonlinear regression Gaussian process analysis without considering the relationship between hydrogeological features and water discharge rate.

Generally, the current research on groundwater movement in tunnels mainly focuses on the influencing factors, the seepage characteristics of surrounding rock, and the seepage theory of the fractured rock mass. However, the research on the change and the law of regional groundwater in super-long tunnels of the mountainous area is still insufficient [46]. Therefore, it is necessary to do research on dynamic change characteristics of groundwater and the prediction of water inflow relying on the super-long tunnel in the western mountainous area of China. In this thesis, based on detailed hydrogeological data and engineering geological data of Daxiangling tunnel, which is a super-long mountain tunnel, a three-dimensional numerical model of the tunnel area is established. After verifying the accuracy of the model, dynamic change characteristics of groundwater under different conditions are analyzed and the tunnel water inflow is predicted with the numerical method and the groundwater dynamics method. The research results are expected to provide theoretical support and guidance for the waterproof and drainage design of mountain tunnels in a complex environment, to provide suggestions for the treatment and prevention of tunnel water inrush disasters, and to reduce the safety risks of tunnel construction.

This paper is organized as follows. Section 1 describes some previous works related to groundwater movement and water inflow of tunnels. Section 2 displays the regional engineering geological condition and hydrogeological characteristics of Daxiangling tunnel. Section 3 explains the establishment and verification of the three-dimensional numerical model of Daxiangling tunnel. Section 4 discusses the findings on dynamic change characteristics of groundwater and water inflow. Finally, Section 5 concludes the current study.

\section{Engineering Survey}

\subsection{Topography and Geomorphology}

Daxiangling tunnel is a typical project of road tunnels in the western mountainous area of China and the important control engineering project of the Beijing-Kunming expressway. It is more than $10 \mathrm{~km}$ in length and is located in the middle of Ya' an City of Sichuan province. In terms of topography and geomorphology, Daxiangling tunnel belongs to the middle and high mountain area on the edge of the basin between the Sichuan Basin and the Qinghai-Tibet Plateau. Within the range of the tunnel area, the ridge valley extends in the far distance. The valley is steep and deep, along with having great differences in elevation. The average elevation in the tunnel area is about $2800 \mathrm{~m}$ and the elevation of the highest point is $3388 \mathrm{~m}$. Daxiangling structural belt is a natural watershed with a steep hillside traversing the middle of the Daxiangling tunnel toward the northwest. There are many multiple terraces on both sides of the Daxiangling tunnel.

The topographic and physiognomic sketch of the tunnel area is shown in Figure 2. 


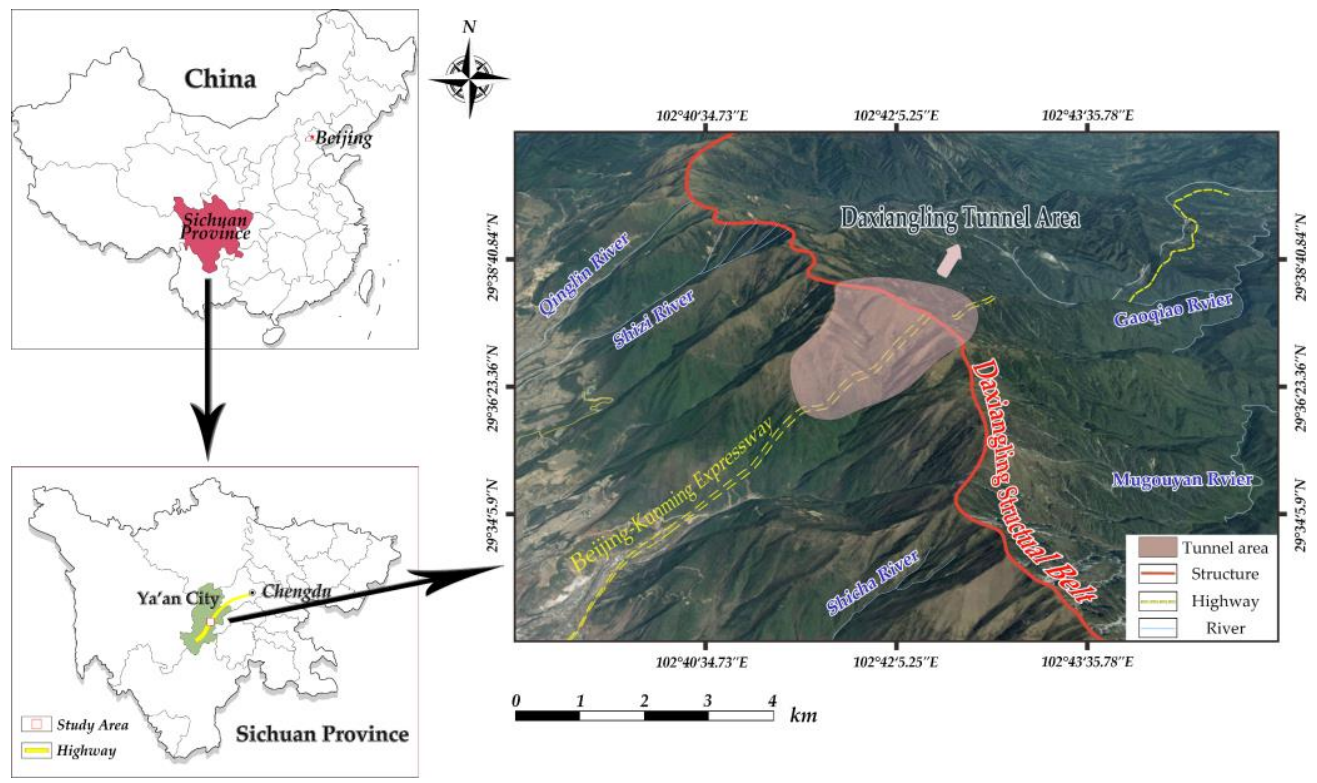

Figure 2. Topographic and geomorphological sketch of study area.

\subsection{Regional Geological Conditions}

Due to the long-term geological tectonism, a special structural area of " $Y$ " shape is formed, which is mainly composed of NE, NW, and SN structural belts. Interlacing and overlapping of structural belts results in the complexity of geological structures and development of faults and folds.in the region.

The Daxiangling tunnel area is located on the SE side of the Y-shaped structural area, which is influenced by multiple secondary structural units, such as Longmen mountain structural belt, Xiaojin structural belt, Xianshui river structural belt, Jintang structural belt, and Kangding structural belt. Its structural unit is Daxiangling structural belt. The Daxiangling anticline is the controlling structure of the tunnel area, which is bounded by the Caodaping fault to the northeast and the Baohuang fault zone to the southwest. The nucleus of the Daxiangling anticline is raised and its wings are roughly symmetrical. The regional structure of the Daxiangling tunnel area is given in Figure 3.

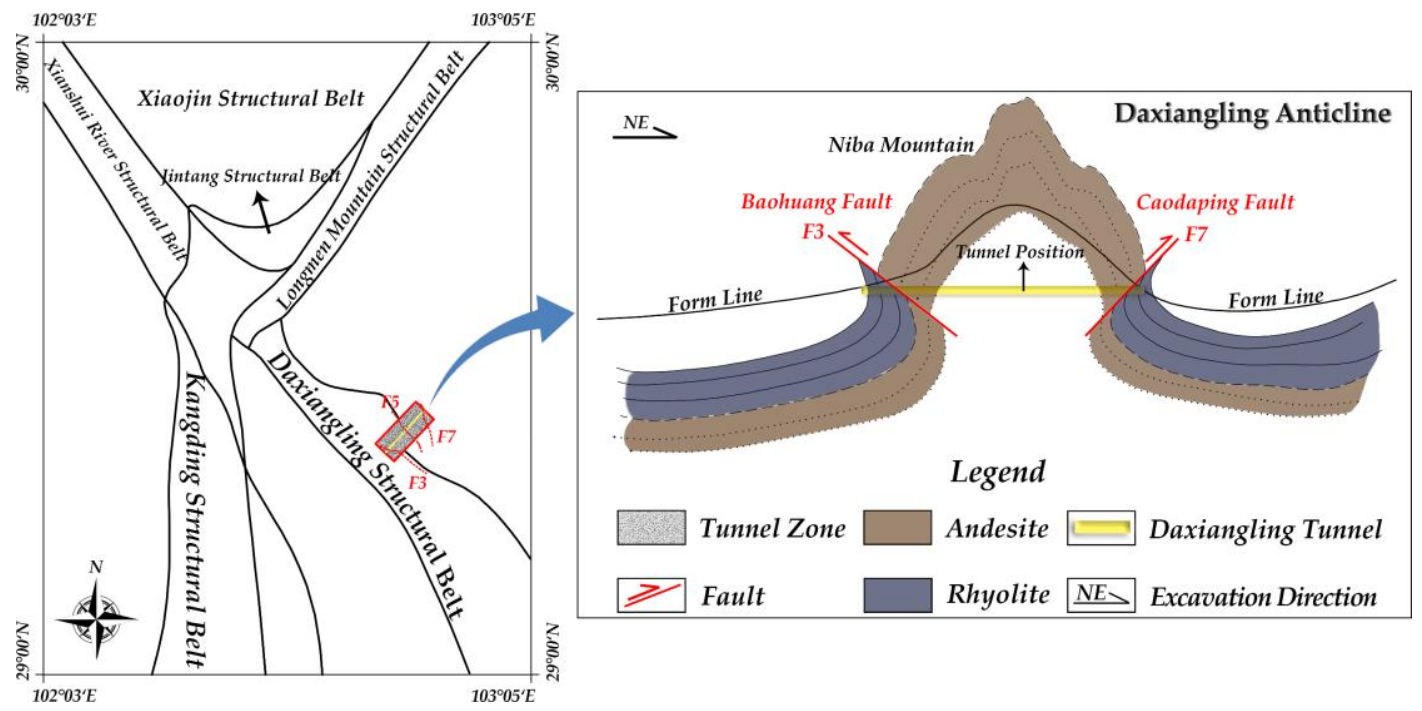

Figure 3. Regional structure of the Daxiangling tunnel.

The dominating geological structures passing through the Daxiangling tunnel include two thrust faults and five compression torsion faults. Most faults tend to be northeast-southwest oriented, 
reflecting the control of regional structural patterns. As shown in Figure 4 and Table 2, we can observe the fine-detail information of all the faults, including specific location, occurrence, and type.

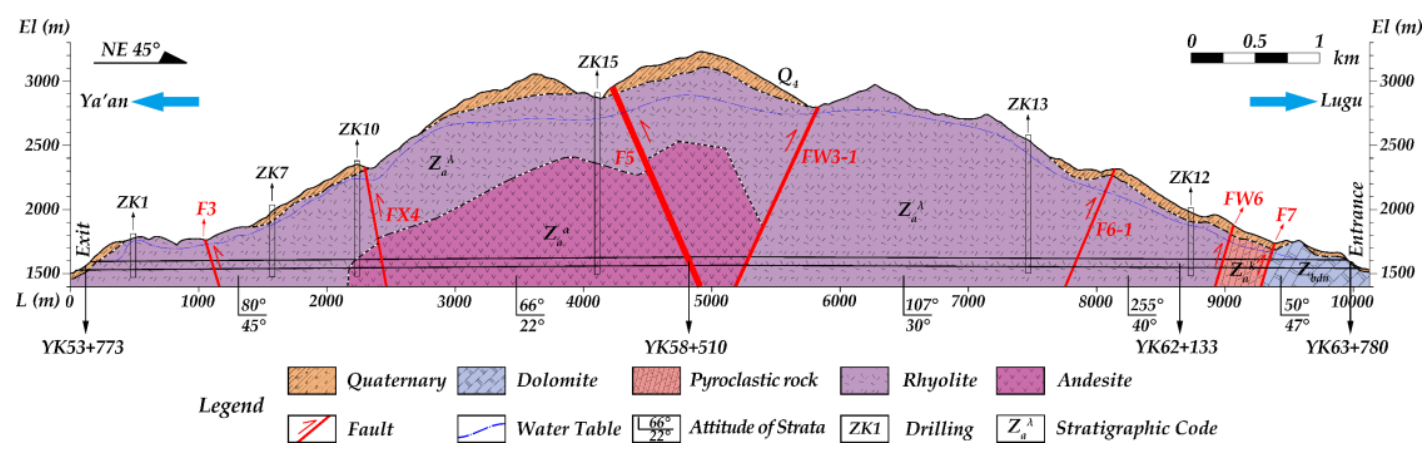

Figure 4. Longitudinal profile map of the Daxiangling tunnel.

Table 2. List of faults in the Daxiangling tunnel area.

\begin{tabular}{ccccc}
\hline Number & Position & Occurrence & Type & Width of Fault Fracture Zone (m) \\
\hline F3 & YK54 + 605 & $225^{\circ} \angle 50-60^{\circ}$ & thrusting & $22-35$ \\
FX4 & YK56 +180 & $230^{\circ} \angle 80^{\circ}$ & compressive-torsional & $20-30$ \\
F5 & YK58 +510 & $240-250^{\circ} \angle 50-70^{\circ}$ & compressive-torsional & $18-50$ \\
FW3-1 & YK59 +500 & $25-35^{\circ} \angle 65-75^{\circ}$ & compressive-torsional & $20-30$ \\
F6-1 & YK61 + 540 & $55-65^{\circ} \angle 60-75^{\circ}$ & compressive-torsional & $33-45$ \\
FW6 & YK62 +670 & $40-50^{\circ} \angle 65-75^{\circ}$ & compressive-torsional & $15-25$ \\
F7 & YK63 +040 & $80-85^{\circ} \angle 55-65^{\circ}$ & thrusting & $22-50$ \\
\hline
\end{tabular}

The strata passing through the Daxiangling tunnel of the area are mainly magmatic strata and sedimentary strata. The lithology of the lowermost stratum of the Daxiangling tunnel is andesite and rhyolite of the Lower Sinian, which are followed by pyroclastic rock and dolomite of the Upper Sinian. The regional surface is covered with the Quaternary stratum. The sequence and lithology of each stratum are given in Figure 4 and Table 3 for the corresponding rock types.

Table 3. Stratigraphic lithology table of Daxiangling tunnel area.

\begin{tabular}{ccccc}
\hline Erathem & System & Series & Code & Brief Description of Lithology \\
\hline \multirow{3}{*}{ Cenozoic } & Quaternary & Holocene & $Q_{4}$ & Sandy soil, Clastic stone \\
& & Pleistocene & $Q_{3}$ & Clay, Gravel pebble layer \\
& & $Q_{1-2}$ & Silt, Gravel pebble layer \\
\hline \multirow{3}{*}{ Proterozoic } & \multirow{3}{*}{ Sinian } & the upper & $Z_{b d n}$ & Dolomite \\
& & & $Z_{b q}{ }^{k}$ & Shale and dolomite interbed \\
& & & $Z_{a}{ }^{\lambda}$ & Pyroclastic rock \\
& the lower & $Z_{a}{ }^{\alpha}$ & Rhyolite \\
& & & & Andesite \\
\hline
\end{tabular}

\subsection{Regional Hydrogeological Characteristics}

Daxiangling structural belt is the watershed in the tunnel area, separating two relatively independent hydrogeological units, which are known as the Qingyi River system and Dadu River system. The rivers in the northeast of the Daxiangling structural belt belong to Qingyi River system. The rivers in the southwest region belong to Dadu River system. As shown in Figure 5, the regional hydrogeological map of the Daxiangling tunnel includes all the river systems mentioned. The hydrogeological characteristics of the main rivers in the tunnel area are shown in Table 4. 


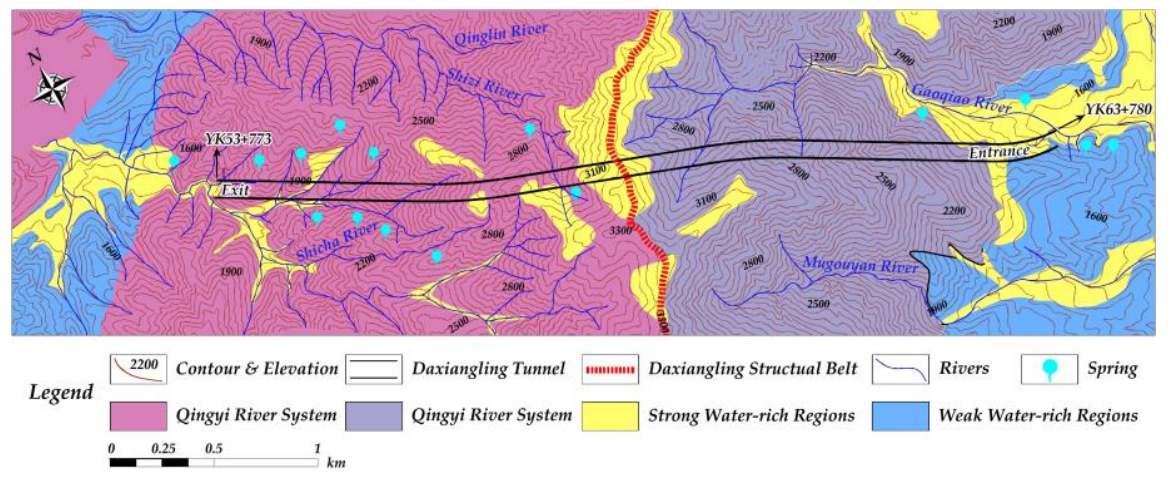

Figure 5. Regional hydrogeological map of the Daxiangling tunnel.

Table 4. The main rivers near the Daxiangling tunnel.

\begin{tabular}{ccccc}
\hline Name & Length $\mathbf{( k m )}$ & Basin Area $\left.\mathbf{( k m}^{\mathbf{2}}\right)$ & Average Slope (\%) & Water System \\
\hline Gaoqiao River & 7.5 & 37.5 & 27.5 & Qingyi River system \\
Muyangou River & 10 & 70 & 16 & Qingyi River system \\
Shicha River & 8 & 24 & 22 & Dadu River system \\
Qinglin River & 7 & 14 & 27 & Dadu River system \\
Shizi River & 8.5 & 25.5 & 19 & Dadu River system \\
\hline
\end{tabular}

There are four types of groundwater in the region, including quaternary pore water, volcanic bedrock fissure water, pyroclastic rock fissure water, and karst water. Quaternary pore water is mainly distributed in the middle and upper part of the Daxiangling anticline. Volcanic bedrock fissure water mainly occurs in rhyolite and andesite strata, which is not evenly distributed. Pyroclastic rock fissure water is distributed in the Sinian clastic rock strata. Karst water mainly occurs in the exit section of the tunnel.

\section{Numerical Simulation}

\subsection{Numerical Model and Grid Division}

The numerical model in this paper is the basis of the groundwater system simulation, in which the groundwater system, engineering geological conditions, and hydrogeological conditions are scientifically generalized. In this model, the objects of study are regarded as an organic whole and relevant data are incorporated into the digital characteristics of groundwater systems. The model consists of several hydro-stratigraphic units. The groundwater inflow and outflow in the model reach a stable equilibrium state through the principle of water balance.

The longitudinal section direction of the tunnel is regarded as the $X$-axis direction. The length of the $X$-axis is $11,080 \mathrm{~m}$, which is also the length of the Daxiangling tunnel. According to the theory of groundwater flow system, the range of numerical simulations of the regional water flow field in the Daxiangling tunnel area should be taken to the natural boundary of the flow system. Consequently, the cross-sectional direction of the tunnel is considered as the $Y$-axis direction. The length of the $Y$-axis is $3300 \mathrm{~m}$, centered on the tunnel. The scope covers all the flow systems in the tunnel area with an area of $36.56 \mathrm{~km}^{2}$. The three-dimensional shape of the numerical model is obtained by means of importing the surface elevation points in the engineering geological map into Visual-MODFLOW. Meanwhile, the elevation direction is taken as the $Z$-axis direction. The value of the lowest point of elevation is set to $1000 \mathrm{~m}$, which is about $500 \mathrm{~m}$ lower than the elevation of the tunnel. The value of the highest point of elevation is $3400 \mathrm{~m}$, which is higher than the highest point in the region.

The three-dimensional numerical model is divided into 169 layers, including $2.265 \times 10^{6}$ units. In the model, the strata are divided according to the actual situation shown in Figure 4 . The geological 
structure consists of the seven faults given in Table 3. As shown in Figure 6, we can observe that all the elements mentioned are displayed in the model.

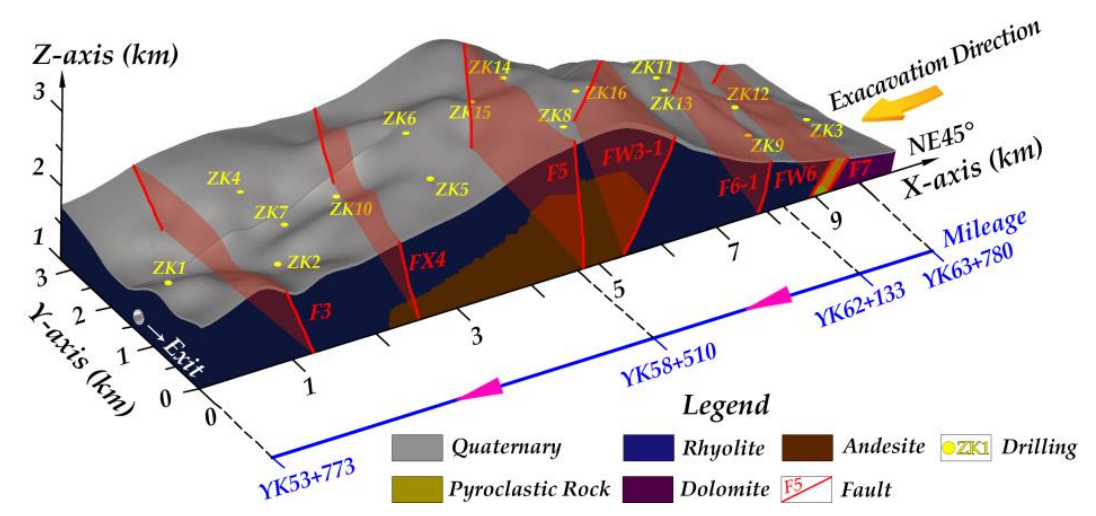

Figure 6. Three-dimensional numerical model diagram of the tunnel area.

\subsection{Boundary Conditions and Initial Conditions}

Natural boundaries, such as surface water systems, geological structures, and ridges, are used as the basis of the boundary divisions. The rivers in the tunnel area are set as the river boundary. The ridge is regarded as the fixed head boundary. The tunnel will become the main drainage channel for groundwater after tunnel excavation. As a result, the tunnel is generalized to the drainage boundary by using the Drain module. On the setting of time, a complete hydrological year is divided into 12 cycles, each of which is divided into 10 steps.

Accurate acquisition of the initial groundwater level in the whole tunnel area is very important for the study of regional flow field. We need to assign the initial groundwater level of each unit. However, the actual initial groundwater level of the whole tunnel area cannot be obtained through drilling in-situ observation owing to the large area of the tunnel area. Therefore, the linear regression analysis of the groundwater level observed by drillings and the surface elevation at the location of drillings is carried out to obtain the initial groundwater level of the whole tunnel area. The relationship between the two elements is finally shown in Figure 7.

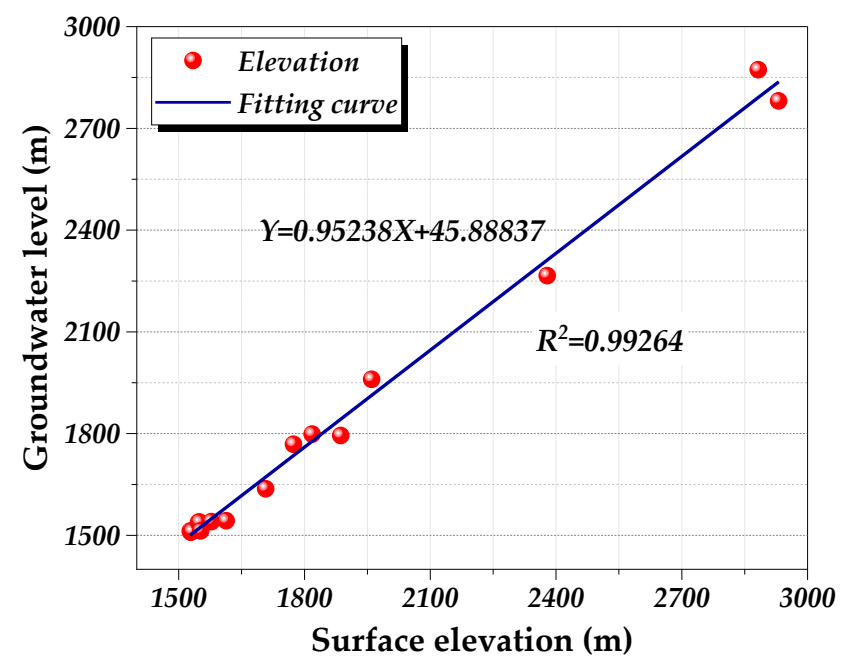

Figure 7. Relationship between surface elevation and groundwater level.

The correlation coefficient $R^{2}$ of the linear regression results is 0.99264 , which indicates that the correlation between groundwater level and surface elevation is very strong. Therefore, the approximately spatial distribution of the groundwater level in the whole tunnel area can be 
estimated with the fitting formula. In the process of model verification, the calculated values obtained by the fitting formula are assigned to each unit as the initial head of the steady flow simulation.

\subsection{Parameter Setting}

In the three-dimensional numerical model, complex strata and geological structures are simplified into multiple hydrogeological units, each of which is independent of each other and has its specific hydrogeological parameters. The relevant parameters of each hydrogeological unit were obtained by means of on-site pumping test, water pressure test, and indoor geotechnical test. The permeation coefficient, effective porosity, and water supply of each hydrogeological unit are shown in Tables 5 and 6.

Table 5. Hydrogeological parameters of each stratum.

\begin{tabular}{cccc}
\hline Stratum & Permeability Coefficient (m/d) & Effective Porosity (\%) & Water Supply (\%) \\
\hline Quaternary & 1.5 & 15 & 10.7 \\
Dolomite & 0.05 & 3 & 2.5 \\
Pyroclastic rock & 0.003 & 2 & 0.5 \\
Rhyolite & 0.08 & 6 & 4 \\
Andesite & 0.04 & 2.4 & 2 \\
\hline
\end{tabular}

Table 6. Hydrogeological parameters of each geological structure.

\begin{tabular}{cccccc}
\hline Fault Number & $\mathbf{K}_{\mathbf{x}}(\mathbf{m} / \mathbf{d})$ & $\mathbf{K}_{\mathbf{y}}(\mathbf{m} / \mathbf{d})$ & $\mathbf{K}_{\mathbf{z}}(\mathbf{m} / \mathbf{d})$ & Effective Porosity $(\%)$ & Water Supply $(\%)$ \\
\hline F3 & 0.57 & 0.57 & 0.57 & 10 & 7.2 \\
FX4 & 0.4 & 0.4 & 0.4 & 8.2 & 6.3 \\
F5 & 0.5 & 0.5 & 0.5 & 10 & 6.8 \\
FW3-1 & 0.5 & 0.5 & 0.5 & 10 & 6.8 \\
F6-1 & 0.5 & 0.5 & 0.5 & 10 & 6.8 \\
FW6 & 0.4 & 0.4 & 0.4 & 8.2 & 6.3 \\
F7 & 0.5 & 0.5 & 0.5 & 10 & 6.8 \\
\hline
\end{tabular}

\subsection{Cases Setting}

According to the actual situation of the right-side excavation of the Daxiangling tunnel, there are three cases in the numerical calculation. The details are shown in Table 7.

Table 7. Numerical simulation cases of regional water flow field in tunnel area.

\begin{tabular}{|c|c|c|c|c|}
\hline Cases & Specific Condition & $\begin{array}{l}\text { Simulated } \\
\text { Time }\end{array}$ & $\begin{array}{l}\text { Groundwater } \\
\text { Flow Pattern }\end{array}$ & Purpose \\
\hline $\begin{array}{c}\text { Tunnel } \\
\text { unexcavated }\end{array}$ & 1 & $\begin{array}{l}1 \text { hydrological } \\
\text { year }\end{array}$ & Unsteady flow & $\begin{array}{l}\text { Analysis of dynamic change } \\
\text { characteristics of groundwater }\end{array}$ \\
\hline $\begin{array}{l}\text { Tunnel section } \\
\text { excavation }\end{array}$ & $\begin{array}{l}\text { Excavation to YK62 } \\
\quad+133 \text { mileage } \\
\text { Excavation to YK58 } \\
\quad+510 \text { mileage }\end{array}$ & $\begin{array}{l}1 \text { hydrological } \\
\text { year } \\
1 \text { hydrological } \\
\text { year }\end{array}$ & $\begin{array}{l}\text { Unsteady flow } \\
\text { Unsteady flow }\end{array}$ & $\begin{array}{l}\text { Analysis of dynamic change } \\
\text { characteristics of groundwater } \\
\text { and the prediction of water inflow }\end{array}$ \\
\hline $\begin{array}{l}\text { Tunnel } \\
\text { holing-through }\end{array}$ & 1 & $\begin{array}{l}1 \text { hydrological } \\
\text { year } \\
\begin{array}{l}1 \text { hydrological } \\
\text { year }\end{array}\end{array}$ & $\begin{array}{l}\text { Unsteady flow } \\
\text { Unsteady flow }\end{array}$ & $\begin{array}{l}\text { Analysis of dynamic change } \\
\text { characteristics of groundwater } \\
\text { without waterproof measures } \\
\text { Analysis of dynamic change } \\
\text { characteristics of groundwater } \\
\text { with waterproof measures }\end{array}$ \\
\hline
\end{tabular}

\subsection{Model Verification}

After assigning the initial groundwater level obtained by linear regression analysis to each unit in the model, a steady flow simulation of a complete hydrological year has been carried out. The stable flow simulation is used to verify the model and identify the parameters. 
Comparing the groundwater level obtained by steady flow simulation with the field monitoring data through drillings, it is obvious that there is little difference between the simulated value and observed value, which does not exceed $10 \%$. Therefore, it is certain that the hydrogeological model corresponding to the three-dimensional numerical model is basically consistent with the actual hydrogeological model. The boundary conditions are set reasonably, and the parameters are accurate. Above all, the numerical model can be used to study the regional water flow field. The results of the steady flow simulation will be used as the initial head of unsteady flow simulation.

The comparison of observed and simulated groundwater levels is shown in Figure 8.

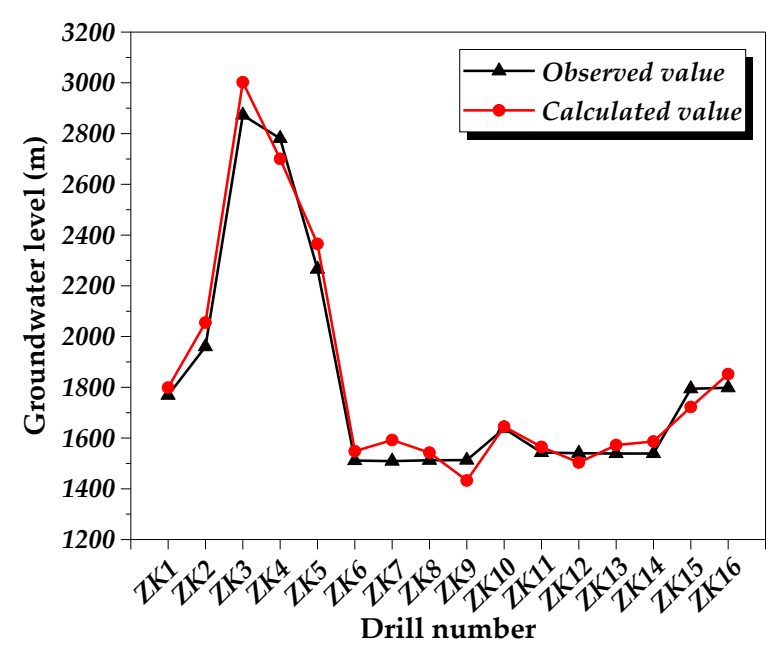

Figure 8. Comparison of observed and simulated groundwater levels.

\section{Results and Discussion}

\subsection{The Dynamic Change Characteristics of Groundwater}

\subsubsection{Tunnel Unexcavated}

There is a groundwater divide formed in the middle of the tunnel and the initial regional water flow field is a hydrostatic pressure field before the tunnel being excavated. The groundwater level is $3235 \mathrm{~m}$ at the top of the mountain, above which drainage units appear (the patches refer to drainage units, which indicate that there is no groundwater). The distribution follows a linear law stating approximately that the level of groundwater decreases with the reduction of the elevation and the groundwater flows to both sides of the mountain while being recharged by the atmospheric rainfall, as shown in Figure 9.

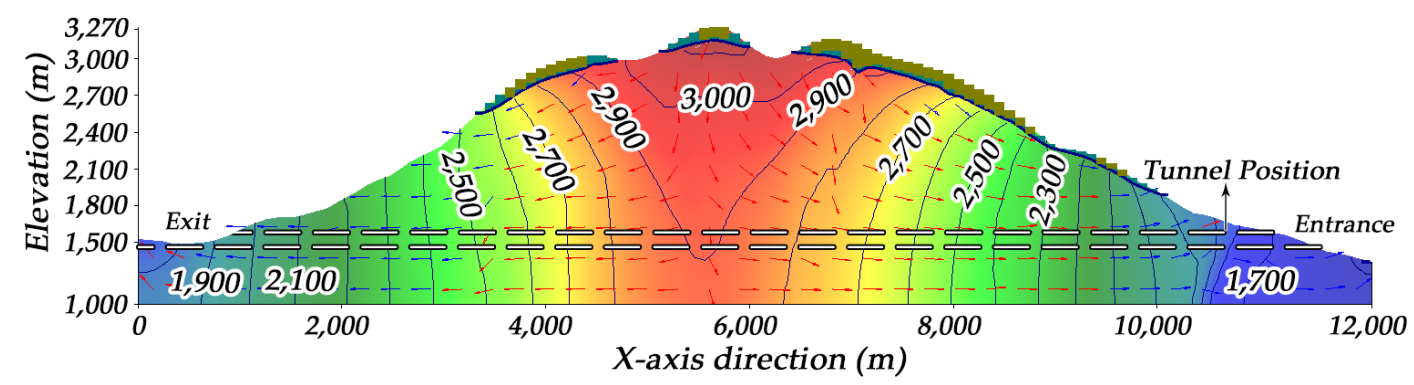

Figure 9. Profile map of the total head distribution on the axis of the tunnel unexcavated in July.

From the perspective of time, the dynamic transformation of the regional water flow field is influenced distinctly by rainfall of seasonal nature, with the highest groundwater level in July. 


\subsubsection{Excavation to the Mileage of YK62 +133}

Tunnel excavating is rather influential on the regional water flow field. As can be seen from the profile map presented in Figure 10a, a groundwater flow channel is already formed and the ground water divide moves towards the unexcavated area. The initial flow direction of the groundwater has changed with groundwater beginning to gush to the tunnel face. The contour of the groundwater head becomes dense around the tunnel face.

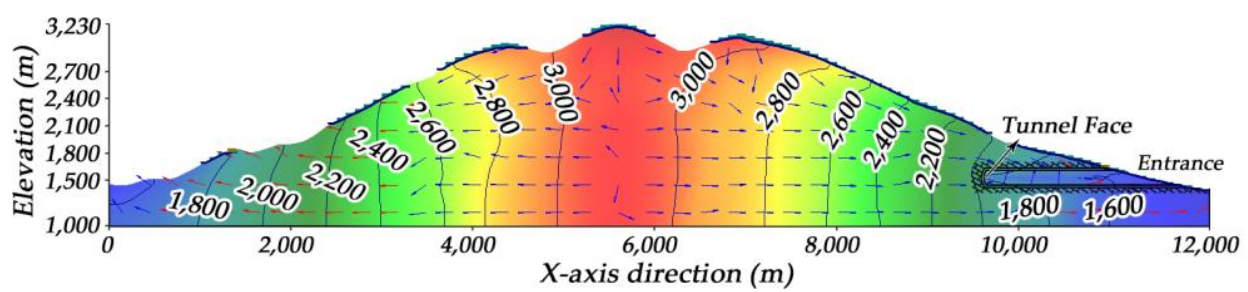

(a)

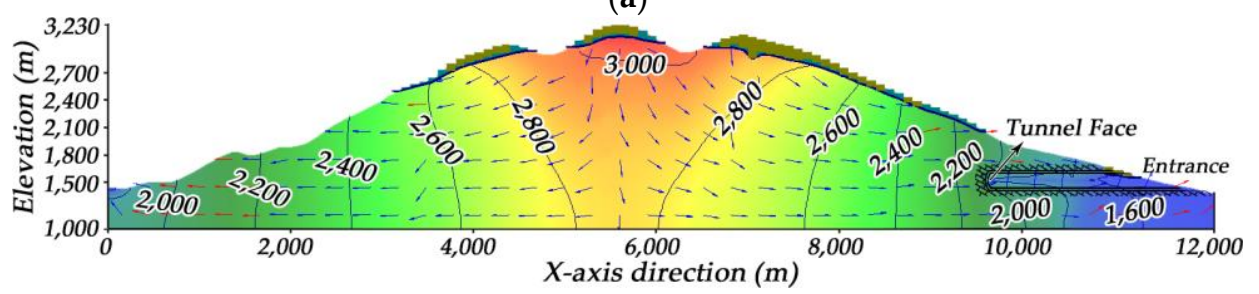

(b)

Figure 10. Profile map of the total head distribution on the axis of tunnel excavated to YK62 + 133:

(a) 30 days later; (b) 360 days later.

It can be sure that the groundwater level declined sharply from $3235 \mathrm{~m}$ to $3000 \mathrm{~m}$ in the plane graph of Figure 11. The area of the drainage unit at the peak is expanded. The influence range of the regional water flow field is orbicular. The tunnel is the center and the radius is $500 \mathrm{~m}$, including the high water pressure area of $250 \mathrm{~m}$ close to the tunnel face.

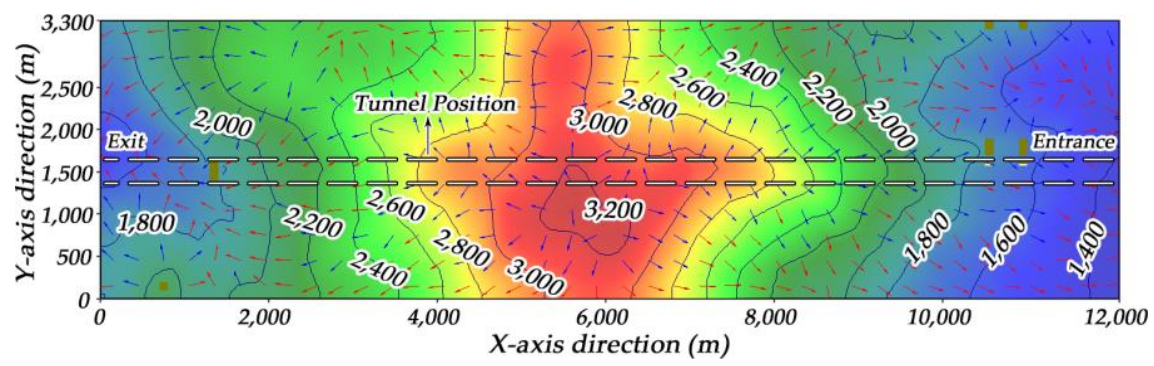

(a)

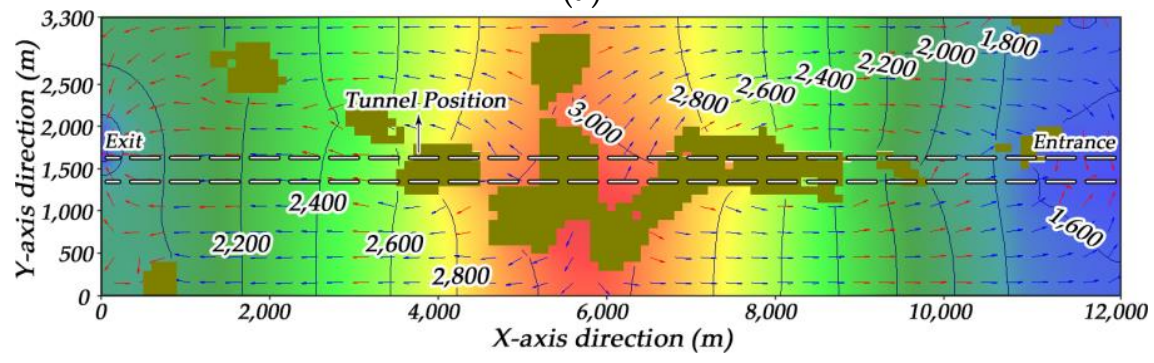

(b)

Figure 11. Plane graph of the total head distribution excavated to YK62 + 133; (a) 30 days later; (b) 360 days later. 


\subsubsection{Excavation to the Mileage of YK58 +510}

The mileage of YK58 +510 is the location where the F5 fault runs through, shown in Figure 4. In the profile map of Figure 12, the groundwater flow channel is further expanded. The result shows that there is a more significant impact on the regional water flow field when excavating to the F5 fault fracture zone, with more intensive water head contours in the excavation section. This is a sign that water inrush is more likely to occur as head contours become denser. The influence range of the water flow field is orbicular. The tunnel is at the center of the location of the fault and the radius is $600 \mathrm{~m}$, which is shown in Figure 13. It takes longer for the groundwater flow field to reach a steady state again due to the influence of fault structure. Obviously, the influence of fault on the regional water flow field is great and continuous.
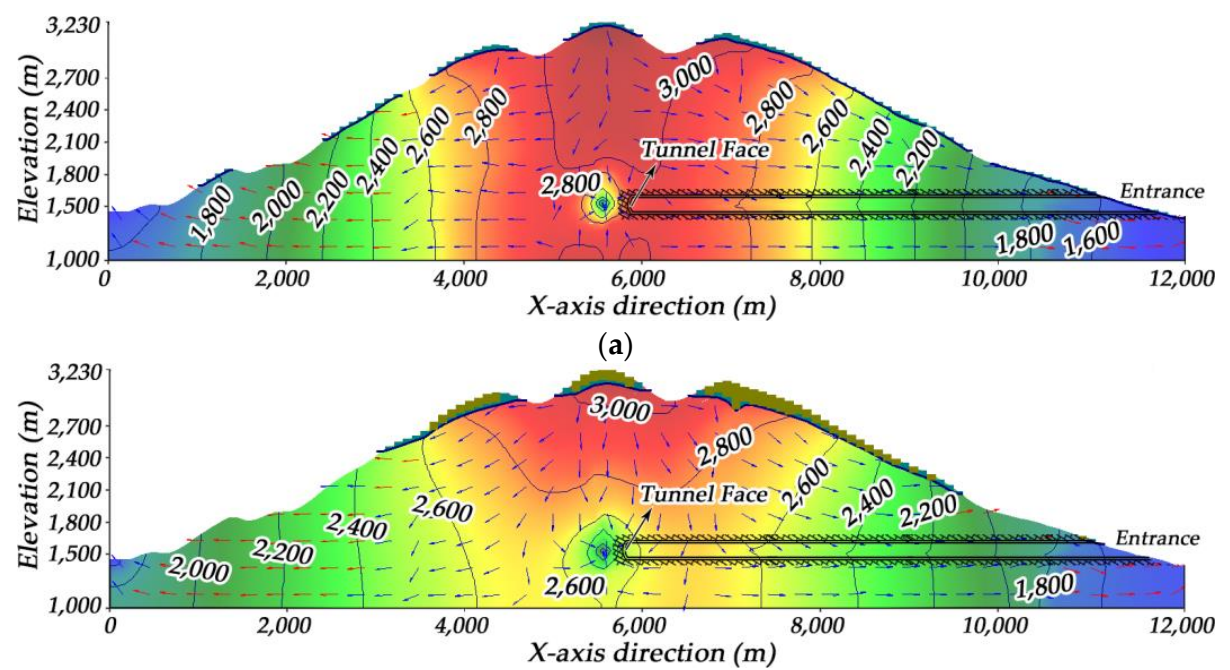

(b)

Figure 12. Profile map of the total head distribution on the axis of tunnel excavated to YK58 + 510: (a) 30 days later; (b) 360 days later.

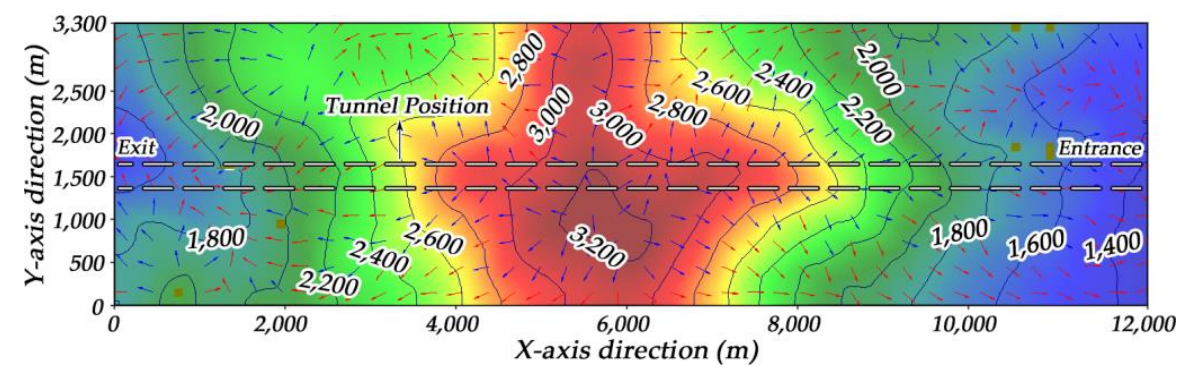

(a)

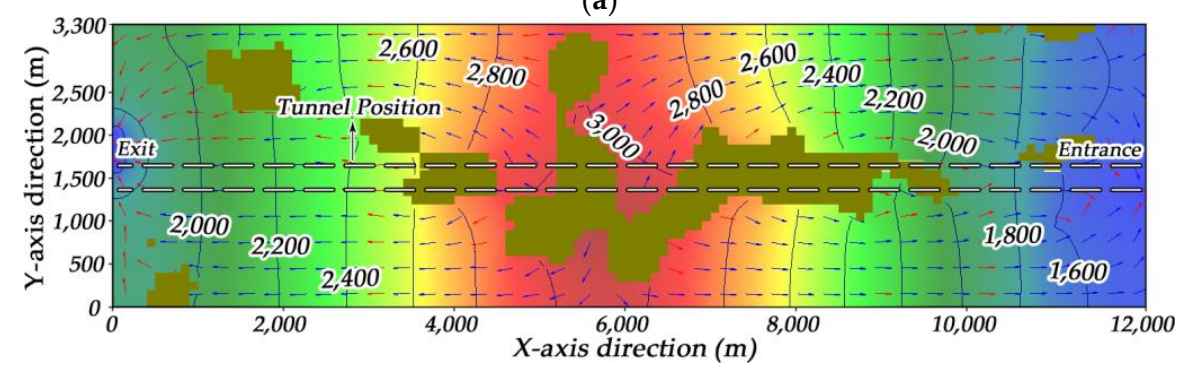

(b)

Figure 13. Plane graph of the total head distribution excavated to YK58 + 510: (a) 30 days later; (b) 360 days later. 


\subsubsection{Tunnel Holing-Through}

A connected linear cavity is formed inside the mountain with tunnel holing-through given in Figure 14. At the same time, the free face of the water level appears and the hydraulic gradient increases. Groundwater flows to the both sides of the mountain, as well as flows vertically downwards to the tunnel. As time goes on, the range of the drainage unit becomes larger. After tunnel holing-through for 360 days, the range of the drainage unit is extended to the area of elevation above $3000 \mathrm{~m}$. The regional water flow field has the largest impact range of $1000 \mathrm{~m}$.

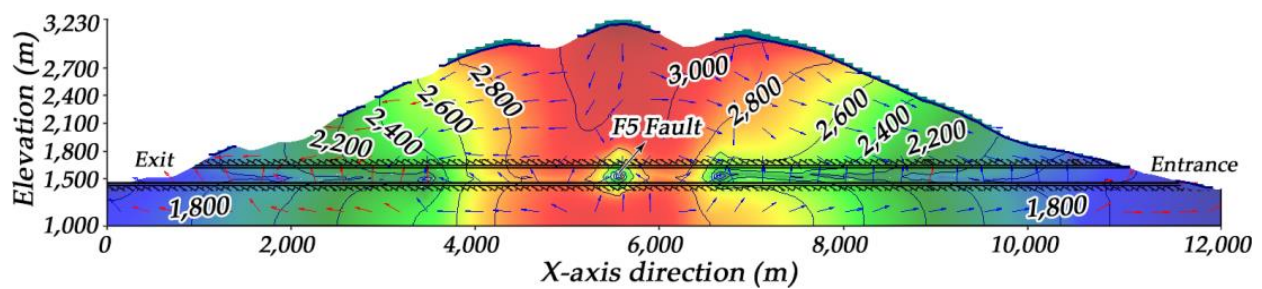

(a)

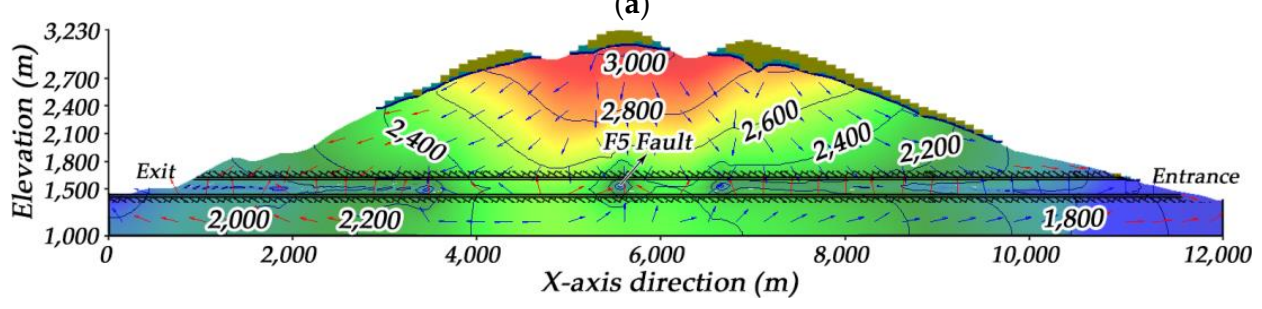

(b)

Figure 14. Profile map of the total head distribution after tunnel through without waterproof measures:

(a) 30 days later; (b) 360 days later.

As the waterproof measures are applied, the range of the drainage unit on the mountain top is significantly reduced. The water head around the tunnel is obviously raised. When the tunnel is completed for 30 days, the groundwater in the high pressure area still flows to the tunnel. However, the distribution law of the regional water flow field is nearly the same as it in the state of nature after 360 days, as indicated in Figure 15a. The groundwater level rises apparently, and the regional water flow field reaches equilibrium quickly with the application of waterproof measures.
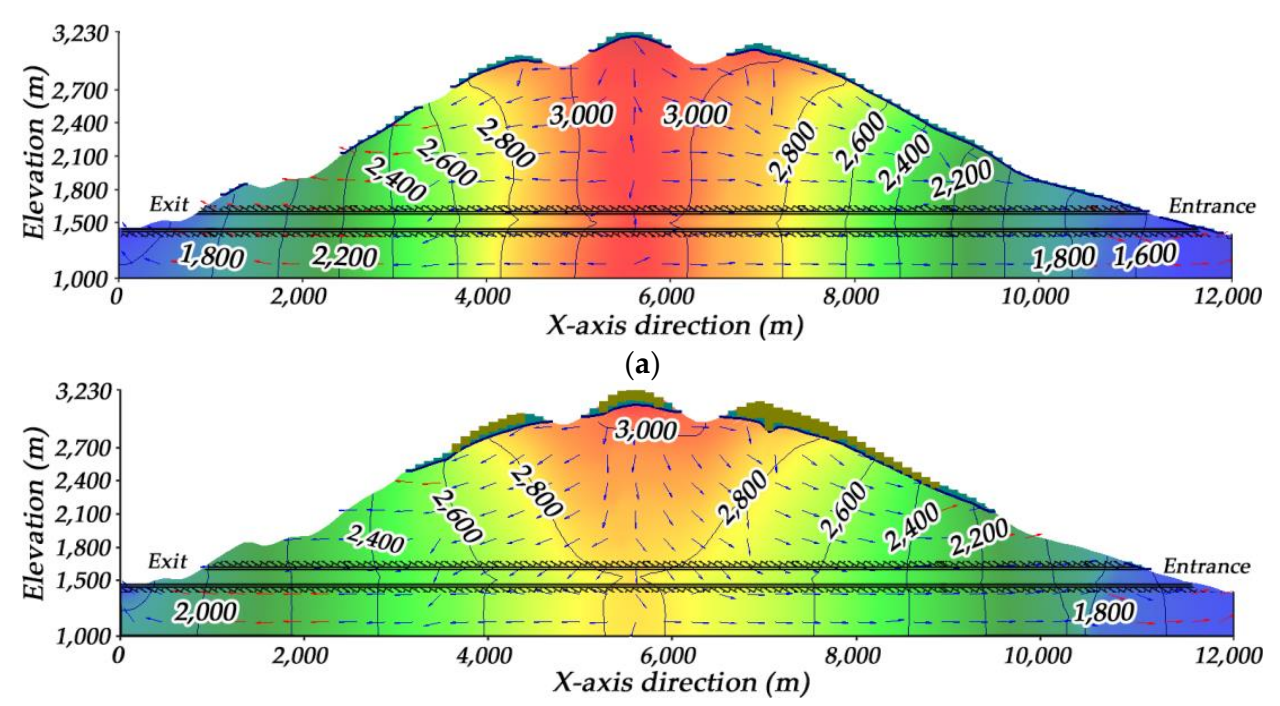

(b)

Figure 15. Profile map of the total head distribution after tunnel through with waterproof measures:

(a) 30 days later; (b) 360 days later. 


\subsection{Prediction of Tunnel Water Inflow}

When the tunnel was excavated to YK62 + 133 mileage and YK58 + 510 mileage, the disaster of water inrush occurred in the excavation section. Water inrush seriously affects the normal construction of the tunnel and the safety of personnel. The situations of water inrush on the site are shown in Figure 16.

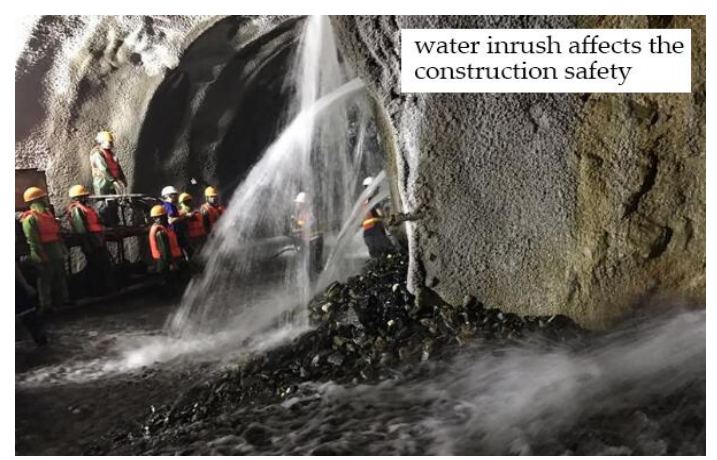

(a)

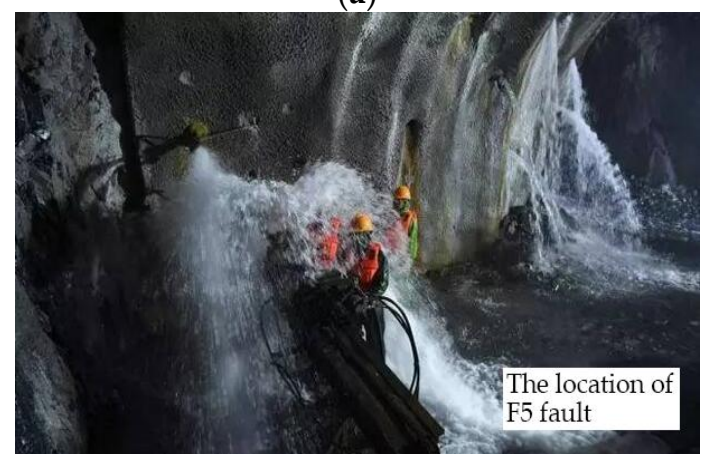

(b)

Figure 16. Water inrush of tunnel: (a) YK62 + 133 mileage; (b) YK58 + 510 mileage.

In this section, the numerical method and the groundwater dynamics method are used to predict the tunnel water inflow.

At present, the commonly used methods for calculating the tunnel water inflow in groundwater dynamics are the Goodman empirical formula method and the Dupuit theoretical formula method. The two formulas are as follows.

Goodman empirical formula [47]:

$$
Q_{0}=L \frac{2 \pi \cdot K \cdot H}{\ln \frac{4 H}{d}}
$$

where the $Q_{0}$ is the maximum water inflow $\left(\mathrm{m}^{3} / \mathrm{d}\right) ; K$ is the permeability coefficient of surrounding rocks $(\mathrm{m} / \mathrm{d}) ; H$ is the value of the hydrostatic head $(\mathrm{m}) ; d$ is the equivalent diameter of the tunnel area $(\mathrm{m}) ; L$ is the axial length of the tunnel water-rich area $(\mathrm{m})$.

Dupuit theoretical formula [48]:

$$
Q_{s}=L \cdot K \frac{H^{2}-h^{2}}{R_{y}-r}
$$

where the $Q_{s}$ is the normal water inflow $\left(\mathrm{m}^{3} / \mathrm{d}\right) ; h$ is the hypothetical depth of water in the gutter $(\mathrm{m})$; $R_{y}$ is the recharge radius of the tunnel water gushing section (m).

The predicted value of tunnel water inflow based on both the groundwater dynamics method and the numerical method are compared with the actual values. The actual values of tunnel water inflow in the field are obtained by pump displacement method. The results are shown in Table 8. 
Table 8. Comparison of predicted and actual values of tunnel water inflow.

\begin{tabular}{|c|c|c|c|c|c|}
\hline \multirow{2}{*}{ Location } & \multirow{2}{*}{ Length (m) } & \multicolumn{2}{|c|}{$\begin{array}{l}\text { The Predicted Value with the } \\
\text { Groundwater Dynamics Method }\left(\mathrm{m}^{3} / \mathrm{d}\right)\end{array}$} & \multirow[t]{2}{*}{$\begin{array}{l}\text { The Predicted Value with the } \\
\text { Numerical Method }\left(\mathrm{m}^{3} / \mathrm{d}\right)\end{array}$} & \multirow[t]{2}{*}{$\begin{array}{r}\text { The Actual } \\
\text { Value }\left(\mathrm{m}^{3} / \mathrm{d}\right.\end{array}$} \\
\hline & & $Q_{0}$ & $Q_{s}$ & & \\
\hline YK62 + 133 & 1647 & $\begin{array}{c}18,871.7 \\
\operatorname{ERR}^{1}(-20.97 \%)\end{array}$ & $\begin{array}{c}5650.3 \\
\text { ERR }(63.78 \%)\end{array}$ & $\begin{array}{c}13,271 \\
\operatorname{ERR}(14.92 \%)\end{array}$ & 15,600 \\
\hline YK58 + 510 & 5270 & $\begin{array}{c}129,952.4 \\
\operatorname{ERR}(-25.68 \%)\end{array}$ & $\begin{array}{c}30,254.8 \\
\text { ERR }(70.74 \%)\end{array}$ & $\begin{array}{c}93,122 \\
\text { ERR }(9.94 \%)\end{array}$ & 103,400 \\
\hline
\end{tabular}

${ }^{1}$ ERR is the relative error, which is the ratio of the difference to the actual value. The difference is obtained by subtracting the predicted value from the actual value.

Apparently, the value of the water inflow calculated by the Goodman empirical formula is smaller than the actual value. The value calculated by the Dupuit theoretical formula is much larger than the actual one. The relative error between the predicted value with the groundwater dynamics method and the actual value of water inflow is too large. There is a larger gap between the predicted value with the groundwater dynamics method and the actual value.

By contrast, the predicted value of water inflow based on numerical method is closer to the actual value with a relative error less than $15 \%$. Overall, in the Daxiangling tunnel, the numerical method of water inflow prediction can effectively calculate the value of tunnel water inflow.

\section{Conclusions}

This paper proposes an analytical method for the study of dynamic change characteristics of groundwater and the prediction of water inflow in a super-long tunnel in the western mountainous area of China. A three-dimensional numerical model validated with field monitoring data is firstly performed to investigate dynamic change characteristics of groundwater under different conditions. Then, the predicted value of tunnel water inflow is obtained by the numerical method combined with the groundwater dynamics method. Finally, the accuracy of the predicted value of tunnel water inflow compared with the actual value is analyzed. The following conclusions are drawn:

(1) The regional water flow field is in a stable state as the tunnel is unexcavated. Seasonal dynamic change has a direct impact on groundwater level. Rainfall is regarded as the most important recharge source of groundwater. The groundwater level will achieve its maximum when rainfall reaches the maximum.

(2) A new groundwater flow channel has been formed with the proceeding tunnel excavation, which makes the groundwater near the tunnel flow directly to the channel. The distribution of water head contours around the tunnel face becomes denser. When the tunnel is excavated into the fault zone, the distribution of water head contours around the cross-section becomes more intensive and concentrated, forming a closed loop of water head contours. This is a clear sign that the water inrush is more likely to occur in the fault zone on account of the presence of more joints, more fractures, and more broken surrounding rocks, which make groundwater easier to pass through. The accurate support and waterproof measures should be taken to prevent water inrush in the fault zone in the course of construction.

(3) A connected linear cavity is formed inside the mountain with tunnel holing-through. Before taking waterproof measures, groundwater flows into the tunnel directly, and the level of groundwater drops rapidly, resulting in the instability of the regional flow field. Since the waterproof measures were adopted in the tunnel, the groundwater level has risen significantly, and the regional water flow field has been restored to balance in a short time. This is more conducive to the safety of tunnel construction and the restoration of the ecological environment.

(4) The accuracy of the numerical calculation method of water inflow for a super-long mountain tunnel based on the three-dimensional numerical model is verified by comparing the calculated results with the actual water inflow of the Daxiangling tunnel. The error between the calculated 
value and the real value is less than $15 \%$. The proposed model provides information critical to the water inflow and tunnel construction safety and can be effectively used to analyze evolution characteristics of the regional water flow field for tunnels of a similar nature.

Author Contributions: Z.Z. analyzed the calculation results. P.X. carried out the numerical simulation and wrote the article. H.Z. offered useful suggestions for the preparation and writing of the paper. K.Z. processed the data.

Funding: The study was supported by the National Key Research and Development Program of China (2016YFC0802202), the General Program of the National Natural Science Foundation of China (51878572) and Sichuan Science and Technology Program (19ZDYF2709).

Acknowledgments: We also highly appreciate the contribution of data collection from Sichuan Communication Surveying and Design Institute. Finally, the authors would like to thank reviewers for useful comments and editors for improving the manuscript.

Conflicts of Interest: The authors declare no conflict of interest.

\section{References}

1. Hong, K. Development and prospects of tunnels and underground works in China in recent two years. Tunn. Constr. 2017, 37, 123-134.

2. He, J.; Gao, B.; Xue, T.; Bai, Y. Consideration on scientific maintenance management of highway tunnel in China. Tunn. Constr. 2018, 38, 51-57.

3. Zhang, H.; Sun, J.C.; Liu, X.C.; Tu, P. Investigation and analysis on the setting of cross passage and auxiliary passage in extra-long highway tunnel. Procedia Eng. 2018, 211, 659-667. [CrossRef]

4. Zhao, Y.; Tian, S.; Sun, Y. Development and planning of high-speed railway tunnels in China. Tunn. Constr. 2017, 37, 11-17.

5. Wang, X.; Zhao, Y. Comment on construction of railway tunnels in China by statistical data. Mod. Tunn. Technol. 2006, 21, 7-17.

6. Zhang, H. Seepage Analysis of Groundwater and Study on Treatment Measures of Pouring Water in Wuduxi Highway Tunnel. Master's Thesis, Chang'an University, Xi'an, China, 2014.

7. Zhang, H.; Chen, L.; Chen, S.; Sun, J.; Yang, J. The spatiotemporal distribution law of microseismic events and rockburst characteristics of the deeply buried tunnel group. Energies 2018, 11, 3257. [CrossRef]

8. Zhang, Z.Q.; Zhang, H.; Tan, Y.J.; Yang, H.Y. Natural wind utilization in the vertical shaft of a super-long highway tunnel and its energy saving effect. Build. Environ. 2018, 145, 140-152. [CrossRef]

9. Zhang, Z.Q.; Shi, X.Q.; Wang, B.; Li, H.Y. Stability of NATM tunnel faces in soft surrounding rocks. Comput. Geotechnol. 2018, 96, 90-102. [CrossRef]

10. Zhang, Z.Q.; Li, H.Y.; Yang, H.Y.; Wang, B. Failure modes and face instability of shallow tunnels under soft grounds. Int. J. Damage Mech. 2019, 28, 566-589. (In Press) [CrossRef]

11. Lai, J.X.; Qiu, J.L.; Fan, H.B.; Zhang, Q.; Hu, Z.N.; Wang, J.B.; Chen, J.X. Fiber bragg grating sensors-based in situ monitoring and safety assessment of loess tunnel. J. Sens. 2016, 16, 1-10. [CrossRef]

12. Wang, X.; Lai, J.; Garnes, R. On the Support System for Tunnelling in Squeezing Ground of Qingling-Daba Mountainous Area: Case Study from Soft Rock Tunnels. Adv. Civ. Eng. 2019. [CrossRef]

13. Maleki, M.R. Groundwater Seepage Rate (GSR); A new method for prediction of groundwater inflow into jointed rock tunnels. Tunn. Undergr. Space Technol. 2018, 71, 505-517. [CrossRef]

14. Cesano, D.; Bagtzoglou, A.C.; Olofsson, B. Quantifying fractured rock hydraulic heterogeneity and groundwater inflow prediction in underground excavations: The heterogeneity index. Tunn. Undergr. Space Technol. 2003, 18, 19-34. [CrossRef]

15. Moon, J.; Jeong, S. Effect of highly pervious geological features on ground-water flow into a tunnel. Eng. Geol. 2011, 117, 207-216. [CrossRef]

16. Farhadian, H.; Katibeh, H. New empirical model to evaluate groundwater flow into circular tunnel using multiple regression analysis. Int. J. Min. Sci. Technol. 2017, 27, 415-421. [CrossRef]

17. Hassani, A.N.; Farhadian, H.; Katibeh, H. A comparative study on evaluation of steady-state groundwater inflow into a circular shallow tunnel. Tunn. Undergr. Space Technol. 2018, 73, 15-25. [CrossRef] 
18. Fernandez, G.; Moon, J. Excavation-induced hydraulic conductivity reduction around a tunnel-Part 1: Guideline for estimate of ground water inflow rate. Tunn. Undergr. Space Technol. 2010, 25, 560-566. [CrossRef]

19. Li, P.F.; Wang, F.; Long, Y.Y.; Zhao, X. Investigation of steady water inflow into a subsea grouted tunnel. Tunn. Undergr. Space Technol. 2018, 80, 92-102. [CrossRef]

20. Sosa, E.M.; Thompson, G.J.; Barbero, E.J. Experimental investigation of initial deployment of inflatable structures for sealing of rail tunnels. Tunn. Undergr. Space Technol. 2017, 69, 37-51. [CrossRef]

21. Raposo, J.R.; Molinero, J.; Dafonte, J. Quantitative evaluation of hydrogeological impact produced by tunnel construction using water balance models. Eng. Geol. 2010, 116, 323-332. [CrossRef]

22. Zhang, W.; Li, Z.; Wang, Q. Cause analysis and counterm easures for water cushing of karst tunnels. Tunn. Constr. 2008, 56, 257-262.

23. Yan, Z.; Li, L.; Gao, Y.; Zhang, C. Finite difference analysis of seepage field in highway tunnel excavation. J. China Foreign Highw. 2007, 78, 120-123.

24. Qian, Q. Challenges faced by underground projects construction safety and countermeasures. Chin. J. Rock Mech. Eng. 2012, 31, 1945-1956.

25. Zhou, Z.; Li, S.; Li, L.; Shi, S.; Song, S.; Wang, K. Attribute recognition model of fatalness assessment of water inrush in karst tunnels and its application. Rock Soil Mech. 2013, 34, 818-826.

26. Yin, Y.; Tian, J.; Zhang, Y. Study on statistical analysis of karst tunnel disaster cases. Highw. Eng. 2018, 43, 210-214.

27. Yang, Y. Research of karst tunnel water bursting hazard risk assessment system in the south west mountainous area. Ph.D. Thesis, Chengdu University of Technology, Chengdu, China, 2009.

28. Chen, Z.; Li, M.; Chen, Z.; Xie, X. Research and treatment of karst water inrush in Huayingshan tunnel. Chin. J. Rock Mech. Eng. 2002, 113, 1344-1349.

29. Yu, C. Based on Statistical Analysis of Southwest China Karst Tunnel Inflow Forecast Analysis. Master's Thesis, Chengdu University of Technology, Chengdu, China, 2013.

30. Li, S.; Xue, Y.; Zhang, Q.; Li, S.; Li, L.; Sun, K. Key technology study on comprehensive prediction and early-warning of geological hazards during tunnel construction in high-risk karst areas. Chin. J. Rock Mech. Eng. 2008, 80, 1297-1307.

31. Zhao, Y.; Hu, B.; Chen, H.; Xiang, W. Impact of tunnel engineering on groundwater environment in karst area. J. Civ. Archit. Environ. Eng. 2018, 40. [CrossRef]

32. Yan, J.; Huang, W. The change of ground water seepage field and water level for the tunnel excavation. J. Transp. Sci. Eng. 2015, 31, 58-63.

33. Gao, X.; Qiu, W.; Kong, C. Test study on the variation law of seepage field during the construction process of high water pressure tunnel. China Railw. Sci. 2013, 34, 50-58.

34. Zhu, C.; Ying, H.; Gong, X. Analytical solutions for seepage fields of underwater tunnels with arbitrary burial depth. Chin. J. Geotech. Eng. 2017, 39, 1984-1991.

35. Zhu, C.; Ying, H.; Gong, X.; Shen, H.; Wang, X. Semi-analytical solutions on seepage field of twin tunnels. In Proceedings of China-Europe Conference on Geotechnical Engineering; Wu, W., Yu, H.S., Eds.; Springer International Publishing: Cham, Switzerland, 2018; pp. 1239-1243.

36. Li, Z.; He, C.; Yang, S.Z.; Yang, W.B. Study of seepage field distribution and its influence on urban tunnels in water-rich regions. Rock Soil Mech. 2018, 39, 1767-1774. [CrossRef]

37. Zhang, W.; Dai, B.; Liu, Z.; Zhou, C. On the non-darcian seepage flow field around a deeply buried tunnel after excavation. Bull. Eng. Geol. Environ. 2017, 49, 365-372. [CrossRef]

38. Wang, J.; Yang, L.; He, J. Trial flow method in numerical calculation of water inflow in deep tunnel. Chin. J. Rock Mech. Eng. 2002, 26, 1776-1780.

39. Zhao, G.; Chen, D.; Zhou, Y.; Chen, C.; Zhang, K. Review of numerical study on groundwater inflow forecasting in deep-buried tunnel construction. Geotech. Investig. Surv. 2017, 45, 27-34.

40. Lin, C.; Li, L.; Han, X. Research on forecast method of tunnel water inrush in complex karst areas. Chin. J. Rock Mech. Eng. 2008, 33, 1469-1476.

41. Li, Z.; He, C.; Yang, S.Z.; Wang, B.; Wang, J.Y. Experimental study on tunnel inflow without considering the influence of excavation disturbance. Chin. J. Rock Mech. Eng. 2016, 35, 2499-2506.

42. Hwang, J.H.; Lu, C.C. A semi-analytical method for analyzing the tunnel water inflow. Tunn. Undergr. Space Technol. 2007, 22, 39-46. [CrossRef] 
43. Li, D.; Li, X.; Li, C.C.; Huang, B.; Gong, F.; Zhang, W. Case studies of groundwater flow into tunnels and an innovative water-gathering system for water drainage. Tunn. Undergr. Space Technol. 2009, 24, 260-268. [CrossRef]

44. Cheng, P.; Zhao, L.H.; Zhang, S.W.; Li, L.; Shen, Z.Q.; Ning, P.F.; Zhang, Z.H. Water inflow forecasting for tunnel considering nonlinear variation of permeability coefficient. J. Cent. South Univ. 2017, 24, 1612-1618. [CrossRef]

45. Li, S.C.; He, P.; Li, L.P.; Shi, S.S.; Zhang, Q.Q.; Zhang, J.; Hu, J. Gaussian process model of water inflow prediction in tunnel construction and its engineering applications. Tunn. Undergr. Space Technol. 2017, 69, 155-161. [CrossRef]

46. Yu, L.; Fang, L.; Dong, Y.; Wang, M. Research on the evaluation method of the hydraulic pressure on tunnel lining according to the range of seepage field. Chin. J. Rock Mech. Eng. 2018, 37, 2288-2298.

47. Lei, S. An analytical solution for steady flow into a tunnel. Groundwater 1999, 37, 23-26. [CrossRef]

48. Nielsen, P. Tidal dynamics of the water table in beaches. Water Resour. Res. 1990, 26, 2127-2134. [CrossRef]

(C) 2019 by the authors. Licensee MDPI, Basel, Switzerland. This article is an open access article distributed under the terms and conditions of the Creative Commons Attribution (CC BY) license (http://creativecommons.org/licenses/by/4.0/). 